\title{
On the Origins of Marxist Geography--A Recount of David Harvey's Turn to Urban Studies
}

\author{
Zhiyong Liu \\ The College of Literature and Journalism, Sichuan University, Chengdu 610065, China. \\ taikonaut2005@163.com
}

\begin{abstract}
This thesis gives a recount of the origins and early development of David Harvey's Marxist criticism of capitalist urban society. To deal with the problems of the city, he attempts first to apply the geographical knowledge to urban social issue with a cross-disciplinary perspective and integrates the two seemingly separate fields through the close ties between social processes and spatial form. With the inclusion of the social dimension into urban social studies, Harvey eventually turns from Fabian socialism to Marxist understanding of society, which finally results into the emergence of Marxist geography.
\end{abstract}

Keywords: David Harvey, Marxist geography, social justice, geographical imagination.

\section{Introduction}

David Harvey's influence on Chinese scholars also owe much to the Chinese translation of the same book in 2003, which has been on steady increase ever since. But, among the enthusiasm for the introductions to and applications of Harvey's ideas and concepts, some Chines scholars fails to grasp his trajectory of academic development, which is of vital significance for the effective and appropriate understanding and criticism of capitalist society.

For example, two articles in top academic journals in Chins that discuss the issue of spatial justice in the light of Harvey's theory fail to go back to his foundational book on spatial justice-Social Justice and the City and only allude to his latter books which center most on the theoretical applications and omit the detailed elaborations on basic propositions and principles [1]. Thus, the attempts fall short of its power of explanation in the practical application of Harvey's ideas and concepts to social issues concerning spatial justice.

One of the most important reasons for this problem is that these scholars', without sufficient knowledge about Harvey's early works and his constant turns - from a professional geographer to a social theorist, from a Fabian socialist to a firm Marxist. In his constant efforts to understand capitalist society and its problems, Harvey absorbs a heterogeneous body of knowledge from various sources and integrates them into his unique theoretical framework of historical geographical materialism, which is both a return to Marx's classical works and a contemporary updating of Marxism in the new development of social realities.

Thus, the present thesis intends to give a recount of the formation of Harvey's cross-disciplinary efforts to push from theoretical geography into urban social studies and his change of belief from Fabian socialism to a Marxism. The knowledge of the early stage of formation of Harvey's Marxist geography helps thorough understanding and better applications of his spatial concepts in addressing the actual social issues.

\section{Social Processes and Spatial Form}

Originally trained in geography in Cambridge University, Harvey establishes his leading role in the methodological revolution in geography during 1950s -1960s with his publication of Explanation in Geography in 1969. The success of this book leads to the offer of a teaching post from Johns Hopkins University in Baltimore, where the chaos and ruins left by the civil commotions in the 1960s invoke Harvey's concern for social problems in the cities, especially the problems of urban planning. In his close investigations into the city, Harvey finds that reconstruction efforts after the 1960s' 
unrests do not restore vitality and order to the city of Baltimore, rather, it leads to further poverty of the city residents and even the increasing ghettoization in the city [2].

These findings result in Harvey's doubt about the then dominant urban planning theories of Chicago School. Scholars from these school generally hold so-called scientific views of society and its social process, which, in Harvey's opinion, are in fact mechanical, and thus, prevent them to take social dimensions into considerations. The lack of considerations for the real social processes, subsequently, leads to the neglect of real problems of human in the city, which means, according to Harvey, it deals with "problems in the city" rather than "problems of the city" [3].

To derive insights into the real sources of urban injustice such as poverty and ghettoization, Harvey needs to establish a link between spatial investigations with social processes. Mills proposes the concept of "sociological imagination" for sociologist in Sociological Imagination. According to him, it "enables its possessor to understand the larger historical scene in terms of its meaning for the inner life and the external career of a variety of individuals" [4]. The traditional empirical methods pay attention only to the measurable and verifiable evidence, which leads to the neglect of the well-beings of living individuals. The concept of sociological imagination calls for the return to the concern for the human conditions in the practice of social studies.

Inspired by this concept of Mills, Harvey proposes "geographical imagination" for urban study [5]. This concept is not a simple imitation of Mills' terminology. Rather, it is intended by Harvey, out of the instinct of a professional geographer, to emphasize the vital importance of the insertion of spatial dimension into the study of urban society. This is also one of the earliest advocations for the longneglected spatial dimension in the practice of urban research.

\section{The Trichotomy of Space and the Nature of Space}

To achieve the integration of spatial dimension into social studies in the city, Harvey proposes a tracheotomy of space--solute space; relative space and relational space [6]. The trichotomy goes beyond the traditional concept of space that takes space only as an external container or a passive object, which, in the views of traditional scholars of city planning, waits to be divided and arranged by city planners.

Through the new definition, Harvey succeeds in his attempt to introduce the concept of social space into the investigations on spatial form. But this trichotomy is not a kind of mechanical division of space into separate and isolated categories. The three types are interrelated and mutual penetrated, and thus need to be treated in totality rather than rigid separation.

Furthermore, Harvey goes on to amend the traditional epistemology which is based on the definition and categorization-i.e., it begins with the question "what is space?". Harvey follows Marx's insight that there is "no philosophical answers to a philosophical question" and proposes that "the problem of the proper conceptualization of space" be "resolved through human practice with respect to it". Thus, Harvey turns the question into "how is that human practices create and make use of distinctive conceptualizations of space?" [7]

With such a shift in perspective, Harvey establishes a functional framework for the practical analysis of relationship social processes and spatial form. With this framework, Harvey accomplishes the task of the integration of spatial dimension into social studies of the city.

\section{Social Justice and Marxism}

Harvey begins his investigation of social justice in the city with a detailed survey of existing approaches to the question of social justice. Traditionally, social studies are viewed as a kind of objective and value-free scientific activities. It is a distinct field of study from moral philosophy and the objective observations of social studies are subject to the judgment of absolute ethics. Kant's unsuccessful attempt to bridge the dualism on observation and the values into one coherent philosophy ends in the doctrine of a priori, which offers little help to the practice of investigations. 
It is only this time that Harvey finds a real solution to this dualism. Karl Marx replaces the question of "eternal truths" of ethics with "how the concepts of social justice and morality relate to and stem from human practice". Through this approach, he successfully "collapses the distinction" between observation and the values because "the act of observing is the act of evaluation" that can not be separated in reality [8].

But Harvey does not turn to Marxism in his study of social justice in the city, even after his acceptance of Marx's view on the above-mentioned dualism. He is, like many leftist scholars in Great Britain, a Fabian social reformist in the beginning. So, his Social Justice and the City takes a seemingly inconsistent form - the firm part as "liberal formulations" and the second, "socialist formulations".

In fact, Harvey takes the then pervasive view of justice formulated by John Rawls in his 1971 book, A Theory of Justice, which emphasizes the distributive justice which is to be achieved through the workings of market mechanism. But in the process of his actual investigation of the city of Baltimore, Harvey finds out that production is inseparable from distribution. He finally comes to the realization that social justice is not decided by a system of absolute and eternal values and principles, rather, it depends on the social processes operating in a society as a whole. Thus, Harvey finally turn to Marxist belief that the answer to social justice lies in the study of human practice.

Social Justice and the City is considered by Edward Soja as the most "definitive addenda-setting influence on so many different disciplines", which testifies to the great success and vital significance

\section{Conclusion}

David Harvey's turn from geography to urban social study is a cross-disciplinary attempt to expand the application of geographical knowledge. Besides, his Marxist stance is not a predisposed one. Rather, it comes as a result of long and hard journey of pursuit for adequate understandings of the real human problems in society.

\section{References}

[1]. Chunmin Li. David Harvey's thought on Spatial Justice. Philosophical Trends. (2012) No. 4. p. 34-40. Jian Zhang. David Harvey's thought of Space Justice. Journal of Peking University (Humanities and Social Sciences). Vol. 52 (2015) No. 1, p. 83-89.

[2]. David Harvey, et al. Geographical Voices: Fourteen Autobiographical Essays. Peter Gould, Forrest Pitts, eds. New York: Syracuse University Press. 2002, p. 169.

[3]. David Harvey. Revolutionary and Counter-revolutionary Theory. Antipode. Vol. 4 (1972) No. 2. p. $1-25$.

[4]. C. Wright Mills. He Sociological Imagination. Oxford: Oxford University Press. 1959, p.5.

[5]. David Harvey. Social Processes and Spatial Form: An Analysis of the Conceptual Problems of Urban Planning. Papers of the Regional Science Association. Vol. 25 (1970), p. 47-69.

[6]. David Harvey. Social Justice and the City. Oxford: Basil Blackwell. 1988, p. 11-12.

[7]. David Harvey. Social Justice and the City. Oxford: Basil Blackwell. 1988, p. 14-15

[8]. Edward W. Soja. Postmetropolis: Critical Studies of Cities and Regions. Oxford: Blackwell Publishers Ltd. 2000, p. 105. 